UNIVERSITY

OF DEBRECEN

FACULTY OF

HeALTH

NYíREGYHÁZA

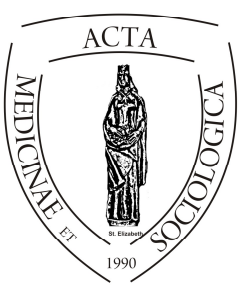

ACTA

MedSoc

VOLUME 6.

2015

\title{
Case study analysis of integrated pupils in czech schools
}

\author{
Věra Kosíková ${ }^{1}$ and Hanna Liberska ${ }^{2}$ \\ ${ }^{1}$ University of West Bohemia, Pilsen, Czech \\ ${ }^{2}$ Kazimierz Wielki University, Bydgoszcz, Poland
}

\begin{abstract}
The aim of the study was to analyze the problems of integrating pupils. On the basis of selected case studies on integrating pupils, especially aiming at pupils with dual exceptionality, the options and opportunities, as well as the limits of integration, are analyzed.

What is the opinion of teachers about the integration and what role do they attribute to educational assistants? The present study focuses on these questions. The aim of this study is not to solve a serious social issue of integration, but to show some specific examples of how successfully or less successfully we can deal with this problem.
\end{abstract}

Keywords: case studies, integration of pupils, pupils with dual exceptionality, educational assistant. 


\section{Introduction}

The study focuses on the problems of integrating pupils with special educational needs, and the exceptionally talented ones. Moreover, the situation of families with these children is difficult (Liberska, 2011, Pisula, 2011). These pupils deserve individual approach from their teachers since they do not quite fit in the other pupils, due to the consequences of their handicap or talent.

We describe two cases representing these types of pupils. There are pupils who are both handicapped and particularly talented. They are so-called twiceexceptional pupils, who pose huge problem for teachers, however teachers must be able to deal with their disorder; usually an autistic spectrum disorder or Asperger's syndrome, yet at the same time these pupils show talent that deserves to be developed. Working with talented pupils can be difficult, let alone when the pupil also has a disorder.

In connection to the problem presented, the question arises, whether the integration process is an answer for all of these pupils, or whether different solutions should be adopted.

The cases described are stories with happy endings, where integration did help these pupils, and also with the help of an assistant pedagogue, their optimal education was ensured (even though in one of the presented cases help came quite late).

\section{Integration of children with Asperger's syndrome}

"To become an outstanding scientist or a great artist, you need to have at least some traits of Asperger's syndrome, which allow you to detach yourself from this world."

Hans Asperger

This disorder falls into the category of disorders of the autistic spectrum. Diagnosed individuals are regarded, by those who surround them, as odd characters, as retarded or sometimes even as a genius. This disorder was described in 1944 by the Viennese psychiatrist Hans Asperger, after whom the disorder was named. It is characterized by a dysfunction of social interaction and by stereotypical behavior. It can be distinguished from autism by the child not suffering from an overall lag or retardation, neither does it suffer from impaired speech. The children often have a normal IQ, frequently, their intellectual disposition is even above average. They manage to memorize traffic timetables, 
they excel in mathematics, physics, they understand computers very well, they have a very good mechanical memory. They are able to recite whole passages from poems or fairy tales by heart. This disorder is more common in boys (Thorová, 2006, p. 211).

\section{Criteria for Asperger's syndrome:}

1. "A qualitative disruption of social interaction - the AS is characterized by the same type of qualitative dysfunctions of social interactions as is the case with autism

2. Limited, repeated stereotypical modes of behavior, interests and activities - the same picture as in autism

3. The disorder causes clinically important dysfunctions in the field of social and professional functioning as well as in other important life situations.

4. The disorder causes clinically important dysfunctions in the field of social and professional functioning as well as in other important life situations. - First words before the second year, sentences with a communicative meaning before the third year

5. Cognitive development (the intellect) is normal, self-help abilities are adequate to the age, as well as adaptive behavior (except social) and exploratory behavior motivated by curiosity

6. Dyspraxia - Is not a prerequisite for the diagnose" (Thorová, 2006, $p$. 186, Attwood, 2005)

Manifestations of these dysfunctions vary. Some manifestations disappear in adulthood, other ones, however, can also emerge. The degree of the disorder is a defining factor for each individual. In adulthood some people are functioning on their own; they are employed, they have a family and they are independent. Others, on the other hand, need life-long assistance. The behavioral manifestations vary from child to child. We never find two identical autistic children (Thorová, 2006e, 2007).

Pupils with diagnosed disorder are integrated into normal classes, as the integration allows them to have individual education plan. They have the option of working with an assistant pedagogue, who will ensure a more successful integration. In the social field, the advantages of integration are also apparent.

Currently, integration has become a popular trend. It should not be forced at all cost, however. In the Czech Republic, there are several schools with autistic therapeutic classes where children are taught by SEN teachers (special education needs teachers) (Vocilka, 1996, p. 34-38, Vocilka, 1996), but situation is not so good in other countries.. 
Autistic children can be taught in the following facilities:

a) common classes; children with a very low degree of dysfunction, like children with Asperger's syndrome or atypical autism, can be accepted,

b) special classes; can be found in normal schools. The number of pupils is reduced (4-6 children), and at their disposal, they have a SEN teacher and an assistant pedagogue.

c) auti-classes

d) special classes for autistic children.

It is very important to consider whether the child should be integrated, or allowed to be educated in a special class. It is extremely important that a SEN teacher shall work with these children.

Pupils with exceptional talent and handicap are often perceived as average.

\section{Pupils with two exceptionalities}

These are pupils with exceptional talent, but also with a handicap - which often disguise each other, or are hidden, therefore these pupils are regarded as average.

Talent and abilities can be related to developmental disorders and this relation can change during the process of development. Due to their reduced communication abilities or social contact deficit, or learning disorders, they often excel in mathematics, physics or astronomy, remember vast amount of data, and are computer savvy. Sometimes these children are called children with „two exceptionalities“" (talented children with some handicap). The presence of an immense talent and, at the same time, a disorder, is very hard to grasp for some people. The children themselves and their families perceive this more as a handicap than an advantage. This group of children also encompasses children with an autistic spectrum disorder, or learning disabilities, or attention deficit disorders, or visual impairment. These children are different from others since they are extremely curious, quickly grasp interrelations between facts, ask unique questions, are interested in things in depth, and are good at exploring connections between facts. They have excellent memory. On the other hand, it is difficult for them to cope with failure and criticism.

This type of connection between talent and disorder is hardly known, even amongst teachers.. These children are lost in society. They do not get sufficient care, their talent is not developed. and it is not given priority over their disorder. Unfortunately, even teachers are not sufficiently educated to recognize and work on their talent. They mostly focus on their disorder. Specialized tests for definig the talent of these children do not exist. Only tests for normal, healthy children are available (Novotná, 2004, Hř́ibková, 2009, Jurášková, 2006). 
The most common combinations of cognitive talent and diagnose are:

- Talented children with specific developmental learning disorders, in particular: dyslexia, dysorthographia, dysgraphia.

- Talented children with behavioral disorders.

- Talented children with Asperger's syndrome.

\section{What impedes successful identification of these children?}

- The stereotypical expectation is that children with some kind of disorder, most commonly those with a learning disorder, are mentally below average.

- Developmental lag in children with learning disorders, in particular in the verbal field, often manifests itself through reading and writing.

- Incomplete information about the child leads to overlooking its strong sides.

- The inability of the child to show its above-average abilities, due to the focus on verbal abilities in classes

The diagnostic methods used with a child suspected to be suffering from the above disorders includes:

data analysis of the family and personal anamnesis, the level of cognitive abilities, evaluation of creativity, determining personality characteristics and features (including social and communication abilities), determining the specifics of work with learning materials and thinking strategies (teaching and cognitive styles), motivation analysis and interest activities or, if applicable, professional orientation, analysis of the results of the pedagogic diagnostics carried out by teachers focused on various personal characteristics of the child/pupil and on their manifestation in the children's behavior, thinking, imagination.

We can differentiate three groups of pupils, which, if not completely diagnosed, display traits and are evaluated as follows:

- Group 1 - students identified as talented but having problems - very often, they are characterized as lazy, unmotivated with a reduced selfefficacy. A learning disability usually is not discovered. The child tries to hide the handicap by excessive effort. The problem grows, especially in those schooling fields where it is required to read or write quickly and correctly or to memorize facts.

- Group 2 - group identified as children with learning disorders but without any special abilities. Here, there is a tendency of the teachers to strongly underevaluate the pupils. As a consequence, intellectual 
abilities are not further developed, the pupil is not given the proper stimuli, loses motivation and often gives up on school altogether.

- Group 3 - above-average abilities and disorders mask one another. The learning disorders of these children are not compensated for, nor are the children identified as being exceptional. At school they are evaluated as average, with no problems, but in fact they are functioning on a lower level than their abilities would allow.

\section{The case of a 17-year-old boy, high school student ${ }^{1}$}

The boy grew up in a normal family, his behavior was, ever since he was little, regarded as odd, yet he was not sent for psychological diagnostics until 16 . Subsequently, he underwent a psychiatric examination.

A striking discrepancy between the tested abilities and school performance became apparent. The boy was diagnosed with exceptional abilities, yet at the grammar school (a gymnázium - a higher level of high school type in the Czech Republic) his grades were average and below the average. He was unable to cope with simple tasks, he did not fulfill his duties, but when assigned with more difficult tasks, especially in mathematics or physics, he excelled. An exceptional ability to deal with logical problems was detected. At the same time, he excelled in the subjects in which he applied a very good long-term memory and vocabulary. His great results, however, were irregular, more than anything else, he appeared to be an absent-minded and reclusive type who had problems in social and emotional fields. He manifested great restlessness, stereotypical behavior and outbursts of anger. He was frequently absent from school, the family and the school suspected an aversion towards school attendance. Neither threats nor persuasion helped at times, the boy was unable to tell why he did not go to school and why he was staying at home and spending his time doing nothing, sitting at the computer. The computer became his best friend, the boy became a great expert, his knowledge and abilities in working with computers exceeded what could be mastered by grammar school (gymnázium) students, paradoxically though, he was only an average pupil in this subject. The normally assigned tasks did not appeal to him at all, so he did not make his homework, did not try to answer questions, and made an impression of an unknowledgeable pupil. He behaved the same way in classes of other subjects, too.

No one had assumed that he suffers from a disorder, just as no one had assumed that he is exceptionally talented.

As a matter of fact, this boy was a case of two exceptionalities.

\footnotetext{
${ }^{1}$ The case was drawn up as part of a baccalaureate of Kristína Kovaczová under the guidance of Dr. V. Kosíková
} 
He was diagnosed with Asperger's syndrome along with exceptional talent. He was also prescribed medication and his further development was watched by a specialized psychologist and psychiatrist.

The boy was placed among integrated pupils, but an individual educational plan was created, which should facilitate learning in the sense that when he is psychically unable to attend school, he could stay at home and fulfill the tasks individually. The teachers are informed about his problems and are prepared to work with him individually. Grading is carried out in a different form now, verbally.

All of this are provided for by the education legislature.

\section{Education legislature in the Czech Republic}

The provision No.73/2005 Sb. about the education of children and students with special educational needs and of exceptionally talented children and students deals in detail with topics such as: special education, principles and educational goals, forms of education, special school types, individual educational plans and the option of using an assigned assistant pedagogue in the class. It also contains a section on the education of exceptionally talented individuals, which also deals with their right to individual educational plans.

"(2) For the purposes of this provision, equalizing measures in educating pupils with disabilities or social disadvantages mean the utilization of pedagogic or special pedagogic methods and procedures, which correspond to the educational needs of pupils, the provision of individual support within the classes and preparation for classes, the utilization of consulting services of the school and school consulting facilities, the individual educational plan and the services of an assistant pedagogue. The school provides these measures based on a pedagogic evaluation of the educational needs of the pupil, the development and the results of the pupil's education, eventually in cooperation with a school consulting facility."

This topic is also addressed in law No. 561/2004 Sb. about preschool, primary, secondary and higher expert or other education. Article 16 focuses on the education of both children, pupils and students with special educational needs and talented children, pupils and students.

"(2) For the purposes of this law, a disability means mental, physical, visual or hearing impairment, speech impediment, parallel affliction by multiple impediments, autism and developmental learning or behavioral disorders."

Article 18 regulates the individual educational plan for these children.

And also provision No. 72/2005 Sb. about the providing of consulting services in schools and at school consulting facilities, which precisely specifies the characteristics, tasks, and the place of individual sessions, such as school, counselor office, or the center (msmt.cz). 


\section{The role of the assistant pedagogue}

School legislature addresses the placement of pupils with special needs (the category in which children with two exceptionalities fall) amongst regular pupils with the help of an assistant pedagogue.

An assistant pedagogue thus is a pedagogic worker who helps pupils with specific needs to manage their learning activities, responds to their needs and helps them, works with the teacher in the class and the parents as well.

The role of the assistant pedagogue is described in article 16 (9) of law No. 561/2004 Sb. as follows: "The director of a kindergarten, primary school, special primary school, secondary school, conservatory or a post-secondary technical school can create the position of an assistant pedagogue for a class or study group in which there is a pupil or student with special educational needs. In case of children, pupils and students with handicaps or health disadvantages a statement from a school advisory facility is required."

An assistant pedagogue is thus assigned to a pupil based on the recommendation of an expert, a psychologist, with the aim to reach the pupil's educational goals. The assistant should also facilitate the work of the teacher who teaches a class with integrated pupils. The work of the assistant pedagogue is demanding, but also very useful, since it facilitates the work not only of the integrated pupil, but also, to some extent, the work of his/ her parents and teachers. His/her work requires expertise founded in social and communication skills, empathy, feeling him/herself into the problems and needs of the handicapped child. An assistant pedagogue is a great asset to pupils with an autistic spectrum disorder and other disorders. The work of the assistants, the possibilities of their utilization and assignment is addressed by provision No. 73/2005 Sb. about the education of children, pupils and students with special educational needs and of exceptionally talented children, pupils and students. Its contents focus mostly on the description of an assistant pedagogue's responsibilities.

According to the above provision, the main activities of an assistant pedagogue are:

a) "helping the pedagogic employees of the school with formative and educational work, helping with communicating with the pupils and their legal guardians and with the community the pupil originates from,

b) supporting the pupils in accommodating to the school environment,

c) helping pupils in classes and with their preparation for classes,

d) providing essential help to pupils with severe handicaps with personal needs and movement during classes and school events outside the 
location where, according to the record in the school registry, education takes place."

\section{Case of an 8-year-old boy, primary school pupil ${ }^{2}$}

The information about the boy was acquired from an interview held with the mother, the teacher and the assistant pedagogue and by observing the boy at school.

After entering the 1st grade, the boy was listed as a regular pupil, he was often disciplined for his aggressive behavior, his exceptional cognitive abilities were overlooked, as he mostly drew attention by his inappropriate behavior. With the replacement of the teacher a change occurred in a few months. Due to the unusual social behavior of the boy, the new teacher recommended the parents, to let him be examined by a pedagogic-psychological consultant.

The boy was diagnosed with:

above average cognitive abilities, sophisticated expressive abilities, attention and activity deficit disorder within the autistic spectrum disorder, hyperactivity, difficulty with orientation in the reality of social life, great difficulty with connecting with peers, Asperger's syndrome (highfunctioning Asperger's syndrome).

On the basis of these results, it was clear that this is a pupil with special educational needs i.e. an integrated pupil (a pupil with two exceptionalities) and it was necessary to create an individual learning plan.

Also, he was assigned an assistant pedagogue and was allowed to be partially home schooled in times when he would not cope with the school environment due to his emotional instability.

The boy grew up in a fully functioning family. The mother and the father have university degrees and they have always cared about the boy and his education.

According to the mother, he was always very impulsive and noisy compared to the other children. He was clumsy dealing with the other children, he was unable to join the other children in games, to introduce himself etc.

Since a very young age he has been very intelligent, though. He was able to read and write at age five. However, there was some difficulty with fine motor skills - e.g. with using scissors or gluing. And due to his inattentiveness, he kept

2 The case was drawn up as part of a baccalaureate of Kristína Kovaczová under the guidance of Dr. V. Kosíková. 
bumping into things and falling. He reacted with irritation to "injustices". Reportedly, his reactions to medical checkups and common medical procedures were borderline hysteric which still persists. He absolutely could not stand having water on his head and face. The parents had no idea about the aggressive behavior in groups before he started going to school, because he never displayed such behavior in the family environment and in kindergarten no one was addressing this issue. The parents did suspect that their child is different with regards to social and emotional behavior, but on the other hand the child's talents veiled his behavioral "deficiencies".

In accordance with the diagnosis, the boy is not able to fully accept the authority of teachers, even though he does accept the authorities he chooses. This fact does complicate school work, nevertheless teachers who had been advised about the situation teach the boy very patiently and they gradually teach him to accept school duties and to respect the authority of adults. The greatest problem for the boy, as confirmed by the teacher and the assistant, is to admit his own errors, he does not like it when teachers and adults criticize him. But according to the mother, his behavior does not represent such as big of a problem as it used to, as the teachers, too, are gradually learning how to treat the boy, to be able to manage various situations that could trigger aggressive reaction.

Ever since the pupil was classified as integrated, his problems started to be resolved by other means than complaints about his behavior. Thanks to social skill training, under the guidance of experienced pedagogues, and thanks to intensive training in the parental environment, the boy is able to maintain normal contacts with his class mates, furthermore, his exceptional cognitive abilities, which used to be overlooked, are being developed.

In conclusion, the integration of the boy has proceeded successfully, the school and the family cooperate well and allow the boy to develop his talents despite the diagnosis. Moreover, the boy was given the opportunity to attend some classes for pupils from higher grades.

It was a stroke of good luck that an accurate diagnosis of an autistic spectrum disorder and the talents was determined in time.

\section{Concusion}

The current education system suffers from several serious problems, which, on part of the Ministry of Education, Youth and Sports, are addressed by legislature, while in practice they are dealt with by schools and individual teachers with the help of experts, mostly psychologists and special pedagogues form pedagogic-psychological consultancy facilities. These problems involve 
pupils with special educational needs and talented pupils; in normal schools the pupils can be listed as integrated and their classes are altered by individual education plans. Some of the pupils (on the basis of a recommendation from a pedagogic-psychological consultant) are entitled to an assistant pedagogue (if the school is able to obtain an assistant).

\section{The set of problems can be considered in the following contexts:}

1. The education legislature secures equal access to education for everyone, the problem, however, is that the schools, in their role of education institutions, are not always capable to secure optimal conditions for all pupils with special educational needs and for talented pupils (in particular, for twice-exceptional pupils, where this is very often an autistic spectrum disorder and the pupil is talented).

2. The teachers are not always sufficiently trained for working with these pupils, there is no systematic education program for pedagogic workers in this field (identification of talents, working with a talented pupil, working with a pupil with an autistic spectrum disorder). Assistant pedagogues are a great help, but their assignment depends on a recommendation by experts and on the situation of the school (among other things, on the financial situation).

3. An integrated pupil is entitled to an individual education plan (since 1993), which should facilitate her or his learning processes. The problem, however, is that a personal cooperation of teachers and experts cannot always be established and the teachers create the individual plans, of how to work with the pupils in classes, on their own, based only on recommendations by the experts. Teachers would welcome the provision of services e.g. in the form of expert consultations, individual help to schools - in particular, when creating individual education plans, and methodological support with working with integrated pupils.

4. Last, but not least, it is very important for a pupil to be diagnosed in time, so the teacher and the parents can be informed about what type of disorder the pupil suffers from or what talent he/she has, so that the optimal care can be provided in the process of education. When a regular school is unable to secure quality education for these pupils (even when using an individual approach based on an individual education plan, or eventually with the help of an assistant for pupils with an autistic spectrum disorder), the question remains whether or not to continue supporting special education - not dismantle it altogether in connection with the integration process. 


\section{Literature}

1. ATTWOOD, Tony. Aspergerův syndrom. Porucha sociálních vztahů a komunikace. 1. vydání. Praha: Portál, 2005. 204 s. ISBN 80-7178-979-8.

2. Documents of the Ministry of Education and Sports, No. 73/2005 Sb.; 561/2004 Sb., 72/2005 Sb.

3. HŘ́lBKOVÁ, Lenka. Nadání a nadaní. 1. vydání. Praha: Grada, 2009. 256 s. ISBN 978-80-247-1998-6.

4. JURÁŠKOVÁ, Jana. Základy pedagogiky nadaných. 1. vydání. Praha: IPPP ČR, 2006. 132 s. ISBN 80-86856-19-4.

5. LIBERSKA, Hanna (ed.). Rodzina $\mathrm{z}$ dzieckiem niepełnosprawnym: możliwości i ograniczenia rozwoju. Warszawa: Difin 2011. 278 s., ISBN 978-83-7641-538-3.

6. PISULA Ewa, TOMASZEWSKI Piotr (eds.). New ideas in studying and supporting the development of exceptional people : essays in honor of Tadeusz Gałkowski. Warszawa: Warsow University Press.2011. 317 s. ISBN 978-83-235-0588-4.

7. THOROVÁ, Kateřina. Poruchy autistického spektra: dětský autismus, atypický autismus, Aspergerův syndrom, dezintegrační porucha. 1. vydání. Praha: Portál, 2006. 453 s. ISBN 80-7367-091-7.

8. THOROVÁ, Kateřina. Poruchy autistického spektra. Informační příručka. 2. vydání. Praha: APLA Praha, 2008, 60 s.

9. THOROVÁ, Kateřina. Výjimečné děti. Aspergerův syndrom. Informační př́ručka. 3. vydání. Praha: APLA Praha, 2007a. 46 s.

10. VOCILKA, Miroslav. Výchova a vzdělávání autistických dětí. 1. vydání. Praha: Septima, 1994. 72 s. ISBN 80-85801-33-7.

11. VOCILKA, Miroslav. Autismus. Praha, 1996. 115 s. ISBN 80-902134-3-X.

\section{Věra Kosíková}

University of West Bohemia, Pilsen, Czech

\section{Hanna Liberska}

Kazimierz Wielki University, Bydgoszcz, Poland 